\title{
The Basic and Middle Education Concept as A Step of Students in Planting Value Establishment since Early
}

\author{
Harningsih Fitri Situmorang \\ Universitas Muhammadiyah Sumatera Utara, Indoneisa \\ Email: harningsihfitri@umsu.ac.id
}

\begin{abstract}
This study aims to find out, about how the importance of primary and secondary education as a way or step for students to be more independent through a work produced through entrepreneurship education, the authors believe that entrepreneurial values are very important to instill early on, because entrepreneurship is the heart of economic defense in every perspective, education is one of the many ways to make students more creative and fully independent. The research method by the author uses the systematic method Literature Review, by gathering several sources of information from journals, books and other articles. To improve the source of reading that will be produced by the reader later. Then after the sources are collected, the new author can conclude what results have been obtained from this reading source.
\end{abstract}

Keyword: middle; education; value

\section{Introduction}

Nowadays entrepreneurship has developed quite rapidly in various countries. Entrepreneurship does not only play a role in increasing output and income per capita, but it involves the introduction or application of changes in the structure of business and society (Albert, 2017). Advances in technology and science have contributed to encouraging entrepreneurial practices that ultimately led to the discovery of new products and services for consumers (Martin et al., 2017). This certainly opens new job opportunities, opens new markets, and in the long run will be able to create business growth in various sectors (Porter, 2019).

In developing countries, businesses that grow a lot in society are generally classified as small businesses, this fact shows that small businesses constitute the majority of community activities that make a significant contribution to the creation of people's incomes (Bendell, 2017). Some of these facts include: $40 \%$ of the volume of business in many countries is carried out by small businesses, $75 \%$ of new jobs are generated by the small business sector, small businesses account for a scattered share of sales in the manufacturing sector, and in almost all countries small businesses are places the birth of entrepreneurship (Rainnie, 2016). However, there is also the fact that $50 \%$ of small businesses fail in the first two years and poor management is the cause of the spread of small business failures (Pearce, 2018).

In Indonesia, economic growth is also determined by the dynamics of the regional economy, while the regional economy is generally generated from small and medium scale economic activities (Ndiaye, 2018). Indeed, the existence of small and medium entrepreneurs is the initial process of the development of industrialization in the region, but in reality on the ground, there are still many obstacles faced by small and medium businesses, internal constraints faced by small entrepreneurs, namely the low quality of human resources, weak access and market share development, weak capital structure, limited technological mastery, weak organization and management, and limited business networks and cooperation with other economic actors (Vinces, 2017). To face these obstacles, an entrepreneur must have a 
strong foundation before establishing and running his business, an entrepreneur must have an entrepreneurial orientation to face competition and increasing market pressures.

The importance of having an entrepreneurial orientation in doing business has been proven in several studies. According to research (Kaur, 2015) which proves that the three dimensions of entrepreneurial orientation namely proactive attitude, risk-taking (decision making), and innovation affect business performance measured by subjective performance (Rufaidah, 2019). Supported by Uddin \& Bose's research (2015) with four entrepreneurial orientation variables namely innovation, proactivity, risk-taking, and autonomy proven to influence business performance. This shows that small businesses who want to improve their performance must certainly have a strong entrepreneurial orientation.

It has been mentioned before that one of the causes of small business failure is poor management, whereas every effort in its management to achieve effective and efficient results requires the application of management principles and the role of leaders or entrepreneurs to carry out the main functions of management in order to achieve the desired business success (Shobaki, 2018). By having an entrepreneurial orientation and good management skills, it is expected to be able to create and run the right strategy for business. According to (Zimmerer, 2008), strategy is a road map of actions compiled by entrepreneurs to achieve the company's mission, goals and objectives. Entrepreneurs must develop a strong strategy based on the previous steps that uses the company's core competencies and strengths as a stepping stone to success (Blank, 2020).

One important aspect of entrepreneurship is marketing, the purpose of marketing is to make profits for companies through the promotion and distribution of products (Bacigalupo,2016). It has become a demand for every entrepreneur to develop marketing strategies in carrying out business activities in order to achieve the targets to be achieved by a business (Moravcikova,2017). Marketing strategy needs to be done to face competition and meet the desires of consumers, for example, entrepreneurs apply a low cost marketing strategy compared to competitors to attract more consumers (Setyawan et al., 2015), found that business strategy had a positive effect on business performance even though 85 percent of the SMEs studied did not carry out overall business strategy planning, business strategy was limited to marketing strategies, in addition, found that in carrying out marketing strategies entrepreneurs engaged in marketing relations with other entrepreneurs so that the creation business network. Amin (2019) stated that marketing communication performs many functions to consumers or target markets, especially to inform and show about how and why the product is used, who the target market is, as well as where and when the product can be obtained. The marketing communication environment by the development of communication process technology has also changed, as has been the case with the recent rise in internal development.

This supports research (Setyawan et al., 2014) which shows that in oil companies, the relationship between companies and their suppliers is bound by strict contracts and even supplier and company relationships are based on transaction cost theory. In hypermarkets, supplier and retailer relationships are based on trust, commitment and satisfaction (Potdar,2018). These three constructs are the basis of relationship marketing. Therefore, the selection and application of the right marketing strategy is important in achieving company goals both large and small (Badi,2017). Entrepreneurs will be faced with various problems, so that a strong management ability is needed to develop marketing strategies in order to continue to survive in the business world (Morrish,2020). The smoothness of a marketing strategy certainly requires a strong entrepreneurial orientation and reliable management capabilities so that business performance can be generated optimally. 


\section{Research Methods}

The research method by the author uses the systematic method Literature Review, by gathering several sources of information from journals, books and other articles. To improve the source of reading that will be produced by the reader later. Then after the sources are collected, the new author can conclude what results have been obtained from this reading source.

\section{Results and Discussion}

\subsection{Definition of Education}

Education is the process of transferring knowledge systematically from one person to another according to standards set by experts, with the transfer of knowledge it is expected to change attitudes, behavior maturity and personality maturity into formal and informal education (Sanford, 2017). Then, according to (Sugihartono,2019) education is a conscious and planned effort made by educators to change human behavior, both individually and in groups to mature humans through teaching and training processes (Siswono,2019).

Education is an effort to attract something in humans as an effort to provide programmed learning experiences in the form of formal, non-formal and informal education in school and outside of school, which lasts a lifetime that aims to optimize the abilities of individuals so that later they can play a role live properly (Gonzalez,2017). Thus, it can be concluded that basically education is the process of transferring knowledge consciously and planned to change human behavior and human maturity through the teaching process in the form of formal, non-formal and informal education. Education is an indicator that reflects a person's ability to be able to complete a job, with an educational background also someone is considered capable of occupying a certain position (Sowell, 2017).

\subsection{Educational Objectives}

Education as a conscious effort certainly requires goals that are formulated because without goals, the implementation of education will lose direction (Mintrop,2019). The purpose of education is used as a guideline on how the educational process should be carried out, and what results are expected in the educational process (Reimers,2019). The goal is a business standard that can be determined, as well as directing the business to be passed and is a starting point for achieving other goals, in addition, the goal can limit the business space so that activities can be focused on what is dreamed of, and most importantly, can provide assessment or evaluation of educational efforts (Mayer,2018). The purpose of education is the first and foremost thing in designing, making programs, and evaluating education.

\subsection{Educational Stage}

Basic Education Basic education is organized to provide the basic provisions needed to live in society in the form of developing attitudes, knowledge, and skills (Fukada,2018). In addition it also functions to prepare students who meet the requirements to attend secondary education (Brahier,2020).

Secondary Education Secondary education, which lasts three years after basic education, is held in a senior high school or equivalent education unit. Secondary education in a downward relationship functions as a continuation and expansion of basic education, and in an upward relationship prepares students to attend tertiary education or enter employment (Azibah,2020). Secondary education consists of general education, vocational secondary, extraordinary secondary, official secondary and religious secondary (Parker,2018). 


\subsection{Understanding of Entrepreneurship Education}

In terms of etymology, education comes from the Greek "Paedagogike". This is a compound word consisting of the word "Pais" which means "Child" and the word "Ago" which means "I guide". So Paedagogike means I guide the child (Hadi, 2008). According to Law No. 20 of 2003 the notion of education is an effort made consciously and planned to create an atmosphere of learning and learning process so that students actively develop their potential to have religious spiritual strength, build personality, self-control, intelligence, noble character, and the skills needed himself, society, nation and state.

Since the beginning of the 20th century, entrepreneurship has been introduced and studied in various countries, for example the Netherlands is known as "ondernemer" and in Germany it is known as "unternehmer" (Guci,2019). In addition, in various countries entrepreneurship has many responsibilities, including responsibility for making decisions concerning technical leadership, organizational and commercial leadership, capital provision, recruitment and handling of labor, purchasing, selling, advertising, and others (Boyed,2019). In 1950, entrepreneurship education began to be initiated in various countries such as Europe, America, Canada. Even since 1970, many universities have taught entrepreneurship, small business management or new business management (Henry,2017). In 1980 nearly 500 schools in the United States provided entrepreneurship education, now in Indonesia, entrepreneurship education has been studied in various schools and colleges (Rashid,2019).

Entrepreneurship and entrepreneurship are active production factors that can mobilize and utilize other resources such as natural resources, capital and technology, so as to create wealth and prosperity through the creation of jobs, income, and products needed by the community (Lampkin,2019). Entrepreneurship is taken from the word entrepreneur and business, entrepreneur is a form of heroism in fighting for something full of courage. Business is an activity carried out to achieve victory in the fight for something (Acs,2017). Entrepreneurship means the ability to have creative ideas and behave can fight for business with risk-making decisions wisely to improve quality of life (Mayer,2017). People who have the ability to see and assess business opportunities, gather the resources needed to take appropriate action, take advantage and have the nature, character and willingness to creatively bring innovative ideas into the real world in order to achieve success or improve income (Brem,2019).

One's education has an influence on one's knowledge and expertise, there are four goals in entrepreneurship education, namely motivational education, knowledge education, skill education, and ability development, therefore, curriculum in entrepreneurship education should cover all four aspects, the earliest entrepreneurship education was introduced by the family environment, parenting and motivational in the family environment is very influential on the characteristics of a child, early on, parents should introduce entrepreneurship, by developing an open attitude, the way to educate children must be changed with guidance and assistance, not prohibition or threat (Zaring,2019. There are many values developed in entrepreneurship education that students should have. But in the development of academic texts, some values are considered the most basic and in accordance with the level of student development, which is 17 values. These values are:

Table 1. Concept of Entrepreneurial Values

\begin{tabular}{cll}
\hline No. & \multicolumn{1}{c}{ Score } & \multicolumn{1}{c}{ Description } \\
\hline 1 & Creative & $\begin{array}{l}\text { Attitudes and behavior that are not easily dependent } \\
\text { on others in completing their duties. }\end{array}$ \\
\hline 2 & Dare to take risks & Think and do things to produce different ways or \\
\hline
\end{tabular}




\begin{tabular}{|c|c|c|}
\hline & & results from existing products or services. \\
\hline 3 & Action oriented & $\begin{array}{l}\text { One's ability to love a challenging job and be able to } \\
\text { take occupational risks. }\end{array}$ \\
\hline 4 & Leadership & $\begin{array}{l}\text { A person's ability to like work that is challenging } \\
\text { and able to take work risks. }\end{array}$ \\
\hline 5 & Hard work & $\begin{array}{l}\text { Take the initiative to act and not wait before an } \\
\text { undesirable event occurs. }\end{array}$ \\
\hline 6 & Honest & $\begin{array}{l}\text { Attitudes and behavior that are always open to } \\
\text { suggestions and criticism, easy to get along, work } \\
\text { together, and mobilize others. }\end{array}$ \\
\hline 7 & Discipline & $\begin{array}{l}\text { Behavior that shows earnest effort in completing a } \\
\text { task and overcoming various obstacles. }\end{array}$ \\
\hline 8 & Innovative & $\begin{array}{l}\text { Behavior that is based on efforts to make himself as } \\
\text { a person who can always be trusted in words, work, } \\
\text { and action. }\end{array}$ \\
\hline 9 & Responsible & $\begin{array}{l}\text { Actions that show orderly and compliant behavior } \\
\text { with various provisions and. }\end{array}$ \\
\hline 10 & Creative & $\begin{array}{l}\text { The attitude and behavior of a person who is willing } \\
\text { and able to perform his or her duties and duties. }\end{array}$ \\
\hline 11 & Cooperation & $\begin{array}{l}\text { Behavior based on efforts to make itself capable of } \\
\text { connecting with others in carrying out actions and } \\
\text { work. }\end{array}$ \\
\hline 12 & Unyielding (tenacious) & $\begin{array}{l}\text { The attitude and behavior of someone who does } \\
\text { not easily give up to achieve one goal with various } \\
\text { alternatives. }\end{array}$ \\
\hline 13 & Commitment & $\begin{array}{l}\text { Agreement about something that is made by } \\
\text { someone, both to himself, himself or others. }\end{array}$ \\
\hline 14 & Realistic & $\begin{array}{l}\text { The ability to use reality factors as a basis for } \\
\text { rational thinking in every decision or action. }\end{array}$ \\
\hline 15 & Curiosity & $\begin{array}{l}\text { Attitudes and actions that always try to know deeply } \\
\text { and broadly about what is learned seen and heard. }\end{array}$ \\
\hline 16 & Communicative & $\begin{array}{l}\text { The pleasure to talk, mingle, and cooperate with } \\
\text { others. }\end{array}$ \\
\hline 17 & Motivation for success & Looking for the best solution. \\
\hline
\end{tabular}

From the definition above, it can be concluded that an entrepreneur must be able to see the opportunities, analyze the opportunities, and make decisions to achieve benefits that are useful for himself or the surrounding environment and the continuation of his business before the opportunity is used by others. Successful entrepreneurs usually spur a dream and try to make it happen because of the high confidence in the success that can be achieved. That entrepreneurship is a discipline that studies the values, abilities, and behavior of a person in facing life's challenges to obtain opportunities with various risks that may be faced. In addition traditional entrepreneurship education focuses on preparing business plans, how to get financing, business development processes and small business management. The education also provides knowledge about the principles of entrepreneurship and technical skills on how to run a business (Ghezzi,2019).

However, students who know the principles of entrepreneurship and business management will not necessarily be successful entrepreneurs. Therefore the field of entrepreneurship studies needs to be specifically designed to be able to develop 
entrepreneurial characteristics, such as creativity, decision making, leadership, social networking, time management, teamwork, and others. Therefore primary and secondary education is an effort to internalize the spirit and mentality of entrepreneurship both through educational institutions and other institutions such as training institutions, training and so on (Ahmad, 2018).

\section{Conclusion}

Entrepreneurship education is very important for entrepreneurs, so they don't fumble in doing their business. With education they will consider everything they will do carefully. Education will form entrepreneurs or business people who are reliable and resilient. Ready to face the challenges they will face. The size of the risk they will carefully consider, do everything with the instructions they know without any uncertainty. Entrepreneurship Education is a planned and applicable effort to increase students' knowledge, intentions and competencies to develop their potential by manifesting in creative, innovative and courageous behaviors to manage risk. Entrepreneurship education is the latest international study and continues to be researched and dynamically developed in all parts of the world. Entrepreneurship education is carried out from universities, high schools, elementary schools to there is a playgroup of entrepreneurship for children. The rise of entrepreneurship education throughout the world is none other than the increasing awareness of the importance of the entrepreneurial character of the younger generation (creative, innovative and courageous to manage risk) and the importance of the position of an entrepreneur on a motor of a country's economic movement.

\section{References}

Al Shobaki, M. J., Abu-Naser, S. S., Salama, A. A., AlFerjany, A. A. M., \& Amuna, Y. M. A. (2018). The Role of Measuring and Evaluating Performance in Achieving Control Objectives-Case Study of" Islamic University".

Amin, M.A.S., and Priansah, P. (2019). Marketing Communication Strategy To Improve Tourism Potential. Budapest International Research and Critics Institute-Journal (BIRCI-Journal). 2(4):

Aziabah, M. A. (2017). The politics of educational reform in Ghana. Educational policy change and the persistence of academic bias in Ghana's secondary education system.

Acs, Z. J., Szerb, L., \& Autio, E. (2017). Global entrepreneurship and development index 2011. Springer International Publishing.

Ahmad, S. Z., Bakar, A. R. A., \& Ahmad, N. (2018). An evaluation of teaching methods of entrepreneurship in hospitality and tourism programs. The International Journal of Management Education, 16(1), 14-25.

Blank, S. (2020). The four steps to the epiphany: successful strategies for products that win. John Wiley \& Sons.

Bacigalupo, M., Kampylis, P., Punie, Y., \& Van den Brande, G. (2016). EntreComp: The entrepreneurship competence framework. Luxembourg: Publication Office of the European Union, 10, 593884.

Bendell, J. (Ed.). (2017). Terms for endearment: Business, NGOs and sustainable development. Routledge.

Badi, S., Wang, L., \& Pryke, S. (2017). Relationship marketing in Guanxi networks: A social network analysis study of Chinese construction small and medium-sized enterprises. Industrial Marketing Management, 60, 204-218.

Brahier, D. J. (2020). Teaching secondary and middle school mathematics. Routledge.

Boyd, B., Henning, N., Reyna, E., Wang, D., Welch, M., \& Hoffman, A. J. (2017). Hybrid 
organizations: New business models for environmental leadership. Routledge.

Brem, A., Bilgram, V., \& Marchuk, A. (2019). How crowdfunding platforms change the nature of user innovation-from problem solving to entrepreneurship. Technological Forecasting and Social Change, 144, 348-360.

Fukada, M. (2018). Nursing competency: Definition, structure and development. Yonago acta medica, 61(1), 001-007.

Ghezzi, A. (2019). Digital startups and the adoption and implementation of Lean Startup Approaches: Effectuation, Bricolage and Opportunity Creation in practice. Technological Forecasting and Social Change, 146, 945-960.

Gumbau Albert, M. (2017). Entrepreneurship, innovation and regional performance: application for the Spanish regions. Entrepreneurship \& Regional Development, 29(34), 271-291.

González Maldonado, R. (2017). Non-formal education: a way out: the realisation of the right to education of refugees through non-formal education activities in Greece (Doctoral dissertation).

Guci, D. A., \& Ghazali, P. L. (2019). Woman Micro Enterprise In Batam. Yayasan Kita Menulis.

Henry, C., Hill, F., \& Leitch, C. (2017). Entrepreneurship education and training: the issue of effectiveness: the issue of effectiveness. Routledge.

I.Dahnial, (2020). The Competency Analysis of Principal Against Teachers In Conducting Distance Learning In Covid-19 Pandemic. (http://jurnaltarbiyah.uinsu.ac.id/index.php/tarbiyah)

I.Dahnial. (2017). Pkn Teacher Competency Analysis in Implementing the 2013 Curriculum in State Junior High School in Stabat District. Journal Of Thematics Volume 6 No. 4 things. 34-36.

I.Dahnial, (2020). Application Of Picture And Picture Learning Models For Education Of Living Environment (Plh) To Increase Teacher Comptension In State State Elementary School. (https://jurnal.stkipalmaksum.ac.id/index.php/jbs)

Lumpkin, G. T., \& Bacq, S. (2019). Civic wealth creation: A new view of stakeholder engagement and societal impact. Academy of Management Perspectives, 33(4), 383404.

Mayer-Schönberger, V., \& Ramge, T. (2018). Reinventing capitalism in the age of big data. Basic Books.

Martín-Rojas, R., Fernández-Pérez, V., \& García-Sánchez, E. (2017). Encouraging organizational performance through the influence of technological distinctive competencies on components of corporate entrepreneurship. International Entrepreneurship and Management Journal, 13(2), 397-426.

Moravcikova, D., Krizanova, A., Kliestikova, J., \& Rypakova, M. (2017). Green Marketing as the Source of the Competitive Advantage of the Business. Sustainability, 9(12), 2218.

Morrish, S. C., \& Jones, R. (2020). Post-disaster business recovery: An entrepreneurial marketing perspective. Journal of Business Research, 113, 83-92.

Mintrop, R. (2019). Design-based school improvement: A practical guide for education leaders. Harvard Education Press.

Mayer, C. (2018). Prosperity: better business makes the greater good. Oxford University Press.

Ndiaye, N., Razak, L. A., Nagayev, R., \& Ng, A. (2018). Demystifying small and medium enterprises'(SMEs) performance in emerging and developing economies. Borsa Istanbul Review, 18(4), 269-281.

Porter, M. E., \& Kramer, M. R. (2019). Creating shared value. In Managing sustainable business (pp. 323-346). Springer, Dordrecht.

Pearce, A., Pons, D., \& Neitzert, T. (2018). Implementing lean-Outcomes from SME case studies. Operations Research Perspectives, 5, 94-104. 
Peña-Vinces, J. C., Casanova, L., Guillen, J., \& Urbano, D. (2017). International competitiveness of small and medium-sized enterprises: Peru, a Latin-American emerging market. Emerging Markets Finance and Trade, 53(1), 150-169.

Potdar, B., Guthrie, J., \& Gnoth, J. (2018). Encouraging shoplifting prevention with quality relationships. International Journal of Retail \& Distribution Management.

Parker, J. D., Taylor, R. N., Keefer, K. V., \& Summerfeldt, L. J. (2018). Emotional intelligence and post-secondary education: what have we learned and what have we missed. In Emotional Intelligence in Education (pp. 427-452). Springer, Cham.

Reimers, F. M., \& Chung, C. K. (Eds.). (2019). Teaching and learning for the twenty-first century: Educational goals, policies, and curricula from six nations. Harvard Education Press.

Rashid, L. (2019). Entrepreneurship Education and Sustainable Development Goals: A literature Review and a Closer Look at Fragile States and Technology-Enabled Approaches. Sustainability, 11(19), 5343.

Rainnie, A. (2016). Industrial relations in small firms: Small isn't beautiful. Routledge.

Rufaidah, P. (2019). Entrepreneurial orientation of SMEs in the creative fashion industry. Journal for Global Business Advancement, 12(2), 254-275.

Sanford, N. (2017). Self and society: Social change and individual development. Transaction Publishers.

Siswono, T. Y. E., Kohar, A. W., Hartono, S., Rosyidi, A. H., Kurniasari, I., \& Karim, K. (2019). Examining Teacher Mathematics-related Beliefs and Problem-solving Knowledge for Teaching: Evidence from Indonesian Primary and Secondary Teachers. International Electronic Journal of Elementary Education, 11(5), 493-506.

Sowell, T. (2017). Education: Assumptions versus history: Collected papers. Hoover Press.

Zaring, O., Gifford, E., \& McKelvey, M. (2019). Strategic choices in the design of entrepreneurship education: an explorative study of Swedish higher education institutions. Studies in Higher Education, 1-16. 